\title{
PRELIMINARY PHYTOCHEMICAL SCREENING AND TO EVALUATE THE ANTI-MICROBIAL ACTIVITY OF HYDRO-ALCOHOLIC and PETROLEUM ETHER EXTRACT OF JASMINE ROOT (NYCTANTHES ARBOUR-TRISTIS). (FAMILY-NYCTAGINACEAE)
}

\author{
ABDUL SAMIM*, SUMIT DAS \\ Girijananda Chowdhury Institute of Pharmaceutical Science Azara, Guwahati, India \\ Email: abdulskypy@gmail.com
}

Received: 23 Apr 2018, Revised and Accepted: 10 Jun 2018

\section{ABSTRACT}

Objective: To estimate the anti-microbial activity of hydro-alcoholic (methanol) and petroleum ether extract of Nyctanthes arbour-tristis (familyNyctaginaceae) in conjugation with phytochemical screening.

Methods: The hydro-alcoholic and petroleum ether extract of the whole root part of the plant Nyctanthes arbour-tristis (family-Nyctaginaceae) was prepared and studied for phytochemical constituents by using various standard methods. The antimicrobial activity of plant extract was performed on two bacterial strains and one fungal strain using disc diffusion method.

Results: The present study shows the phytochemical analysis, antimicrobial activity of the hydro-alcoholic and petroleum ether extract of the root of Nyctanthes arbour-tristis. Various phytochemical analyses revealed the presence of alkaloids, carbohydrates, flavonoids, tannin, phenol, terpenoids, glycosides, saponins respectively. The anti-microbial activity of the plant extract showed significant results against all three of the test organisms.

Conclusion: The present study concluded that the hydro-alcoholic and petroleum ether extract of the root of Nyctanthes arbour-tristis (night flowering jasmine) contains the highly presence of Phytochemical constituents. The hydro-alcoholic and petroleum ether extract of the plant was found to possess promising antimicrobial activity when compared with the standards.

Keywords: Nyctanthes arbour-tristis, Antimicrobial activity, Disc diffusion method, Zone of inhibition, Phytochemical analysis

(C) 2018 The Authors. Published by Innovare Academic Sciences Pvt Ltd. This is an open access article under the CC BY license (http://creativecommons.org/licenses/by/4.0/) DOI: http://dx.doi.org/10.22159/ijcpr.2018v10i4.28462

\section{INTRODUCTION}

Nyctanthes arbortristis is an important and useful plant for its various activity and for its medicinal use as well as cultural use, Nyctanthes arbortristis plant is also known by 'night flowering jasmine' which belong to family oleaceae but now it has been changed and named as nyctaginaceae. This plant mainly developed and growth in the tropical and subtropical area, the place like India, central Australia, USA etc. The name night flowering jasmine is given because of the flowers are seen during night and fall after the mid night. Nyctanthes word is taken from a Greek word that is nyktha and anthos. Whereas nyktha mean night and anthos mean flower.

Nyctanthes arbortristis having a various therapeutic activity like antifungal, anti-pyretic, anti-histaminic, anti-oxidant, anti-inflammatory and much more which going to discover and identify. The aim of using the herbal drug is to minimise the side effect with better efficacy [1-3].

\section{MATERIALS AND METHODS}

\section{Collection of plant materials}

The fresh Nyctanthes arbortristis (night flowering jasmine) was collected from Azara, Guwahati, Assam, India. The plant was authenticated by Dr. P. P. Baruah, professor and head, Department of Botany, Gauhati University, Guwahati, Assam, India. The specimen stored by the department of botany, Gauhati University with Acc. No.-18381 dated 2311-2017 and the reference number is Herb./Bot./GU/2017/166.

\section{Chemicals and reagents}

Petroleum Ether, Methanol, Dragondorff reagent, Mayer's reagent, Wagner's reagent, Benedict's reagent, sulphuric acid, lead acetate, Molisch's reagent, Fehling solution A and B, sodium citrate, copper sulphate, ferric chloride, sodium hydroxide, glacial acetic acid, benzene, chloroform, ammonia, nitric acid, potassium nitrite, gelatine, Beef extract, Peptone, distilled water, agar etc.

\section{Preparation of the plant extract}

The root of night flowering jasmine was collected and washed with tap water, remove all the soil and dirt's and shade dried. Shade-dried roots were grinded and formed powdered, then it passed through sieve number 60 and then the material was extracted with non-polar to polar solvents. At first, the plant material was defatted with petroleum ether then the extraction is carried out in a hydro-alcoholic solvent that is methanol and distilled water in a Soxhlet apparatus by continuous heat extraction. The extract was concentrated in a rotary flash evaporator at a temperature not exceeding $50^{\circ} \mathrm{C}[4]$.

Phytochemical screening

Alkaloids

Reagent: Mayer's test (Potassium mercuric-iodide solution)

Procedure: Filtrates were treated with Mayer's reagent

Result: Yellow coloured precipitate formation indicates the presence of alkaloids.

\section{Carbohydrate}

Reagent: Molisch's Test ( $\alpha$-naphthol solution)

Procedure: Filtrates were treated with 2 drops of alcoholic $\alpha$ naphthol solution in a test tube

Result: Violet ring formation at the junction indicates the presence of carbohydrates.

\section{Flavonoids}

Reagent: Lead acetate Test (lead acetate solution)

Procedure: Plant extract was treated with few drops of lead acetate solution. 
Result: Yellow colour precipitate formation of indicates the presence of flavonoids.

\section{Tannins}

Reagent: Gelatin Test (Sodium Chloride)

Procedure: To the plant extract, $1 \%$ gelatin solution containing sodium chloride was added.

Result: Buff colour precipitate formation indicates the presence of tannins.

\section{Phenols}

Reagent: Ferric chloride solution.

Procedure: Plant extract was treated with ethyl acetate.

Result: Formation of green or violet colour indicates the presence of phenol.

\section{Protein}

Reagent: Xanthoproteic Test (conc. nitric acid)

Procedure: Plant extract was treated with few drops of conc. nitric acid

Result: Yellow colour formation indicates the presence of proteins.

\section{Terpenoid}

Reagent: Salkowski test (conc. sulphuric acid)

Procedure: Few drops of extract treated with few drops of conc. Sulphuric acid, shake it nicely and allowed to stand for some time.

Result: Formation of yellow coloured at lower layer indicated the presence of terpenoids.

\section{Glycoside}

Reagent: Pyridine, sodium nitroprusside, Sodium hydrooxide solution

Procedure: Plant extract are treated with pyridine and add sodium nitroprusside solution.

Result: Blood red colour appears to indicate the presence of glycoside.

\section{Saponin}

Reagent: Foam test (Sodium bicarbonate)

Procedure: Place drug solution in water in a test tube and shake well.

Result: Froat foam is formed [5-7].

Table 1: Microorganisms used for anti-microbial activity

\begin{tabular}{lllll}
\hline Bacterial strain & & & Fungal strain \\
\hline Gram positive organism & ATCC No. & Gram negative organism & ATCC No. & Name \\
Staphylococcus aureus & ATCC3127 & Escherichia coli & ATCC1724 & Candida albicans \\
\hline
\end{tabular}

\section{Microbial strains}

The strain was preserved and kept under fully sterile conditions and grown on Nutrient Agar media for bacteria Staphylococcus aureus and Escherichia coli, Sabourand dextrose agar media for fungi Candida albicans in the Microbiology Laboratory of Girijananda Chowdhury Institute of Pharmaceutical Science, Guwahati, India.

\section{Preparation of extract solution}

The hydro-alcoholic and Petroleum ether extract were prepared by dissolving $0.3 \mathrm{gm}$ in $0.1 \mathrm{ml}$ that is $100 \mu \mathrm{l}$ of 100 percent DMSO and q. $\mathrm{s}$ to $1 \mathrm{ml}$ that is $1000 \mu \mathrm{l}$ with distilled water and stored under refrigerator condition, and then different concentration was prepared according to requirements.

\section{Anti-microbial activity}

\section{Anti-bacterial assay}

Plant extract of concentration 25, 50, $100 \mu \mathrm{l}$ respectively was prepared on the day of experiment after that agar media was placed in the Petri plate and placed in refrigerator for solidifying purpose, after some time it was then taken out and inoculums of each test organism was spread onto the agar plate, so as to achieved a confluent growth different concentration of extract was introduced into the Petri plate. The plate was then incubated at $37^{\circ} \mathrm{C}$ for $24 \mathrm{~h}$, after that zone of inhibition was observed and measured [8].

\section{Anti-fungal assay}

The dextrose agar plate was prepared and inoculated with Candida albicans. The zone of inhibition was measured in millimetres ( $\mathrm{mm}$ ) after $24 \mathrm{hr}$ incubation and compared with the standard antifungal drug (ketoconazole) which was then used as positive control and DMSO 10 percent as a negative control.

\section{RESULTS}

The study shows the phytochemical screening, anti-microbial activity of the hydro-alcoholic and petroleum ether extract of the plant Nyctanthes arbortristis. The yield \% of the extraction of the hydro-alcoholic was $3.65 \%$ and petroleum ether $3.88 \%$.

\section{Phytochemical screening}

Table number 2 showed the result of Phytochemical screening of both extract hydro-alcoholic and petroleum ether. Where the $(+)$ positive mean present and (-) negative mean absent.

\section{Anti-microbial activity}

Table number 3 showed the antimicrobial activity of the plant extract. The hydro-alcoholic and petroleum ether extract of the Nyctanthes arbortristis root having anti-microbial activity against both gram positive and gram negative bacteria and fungi.

Table 2: Phytochemical screening of hydro-alcoholic and petroleum ether extract of root of Nyctanthes arbortristis

\begin{tabular}{llll}
\hline S. No. & Test for constituents & Petroleum ether & Hydro-alcoholic(methanol) \\
\hline 1 & Alkaloids & + & - \\
2 & Carbohydrates & - & + \\
3 & Flavanoids & - & + \\
4 & Tannin & - & + \\
5 & Phenol & - & - \\
6 & Protein & - & + \\
7 & Terpenoids & - & + \\
8 & Glycosides & + & + \\
9 & Saponins & & \\
\hline
\end{tabular}

(-) Absence, (+) Presence 
Table 3: Antimicrobial activity of root hydro-alcoholic and petroleum ether extract Nyctanthes arbortristis observed against the growth of some plant pathogenic bacteria using disc diffusion method

\begin{tabular}{|c|c|c|c|}
\hline \multirow{3}{*}{$\begin{array}{l}\text { Name of the compounds with } \\
\text { concentration }\end{array}$} & \multicolumn{3}{|c|}{ Anti-bacterial activity diameter anti-fungal activity diameter of } \\
\hline & \multirow{2}{*}{$\begin{array}{l}\text { Zone of inhibition (mm) } \\
\text { Escherichia coli }\end{array}$} & \multicolumn{2}{|l|}{ Zone of inhibition (mm) } \\
\hline & & Staphyllococcus aureus & Candida albicans \\
\hline Chloramphenicol $(30 \mu \mathrm{l})$ & 31.26 & 28.55 & ---- \\
\hline Ketoconazole $(10 \mu \mathrm{l})$ & ---- & ---- & 22.27 \\
\hline Hydro-alcoholic $(25 \mu \mathrm{l})$ & 17.65 & 13.14 & 12.34 \\
\hline Hydro-alcoholic $(50 \mu \mathrm{l})$ & 20.10 & 16.22 & 14.24 \\
\hline Hydro-alcoholic $(100 \mu \mathrm{l})$ & 22.58 & 18.77 & 17.19 \\
\hline Petroleum ether $(25 \mu \mathrm{l})$ & 10.18 & 8.87 & 7.12 \\
\hline Petroleum ether $(50 \mu \mathrm{l})$ & 12.08 & 10.11 & 9.57 \\
\hline Petroleum ether $(100 \mu \mathrm{l})$ & 13.8912 .2611 .57 & & \\
\hline
\end{tabular}

Zone including $5 \mathrm{~mm}$ of paper diameter

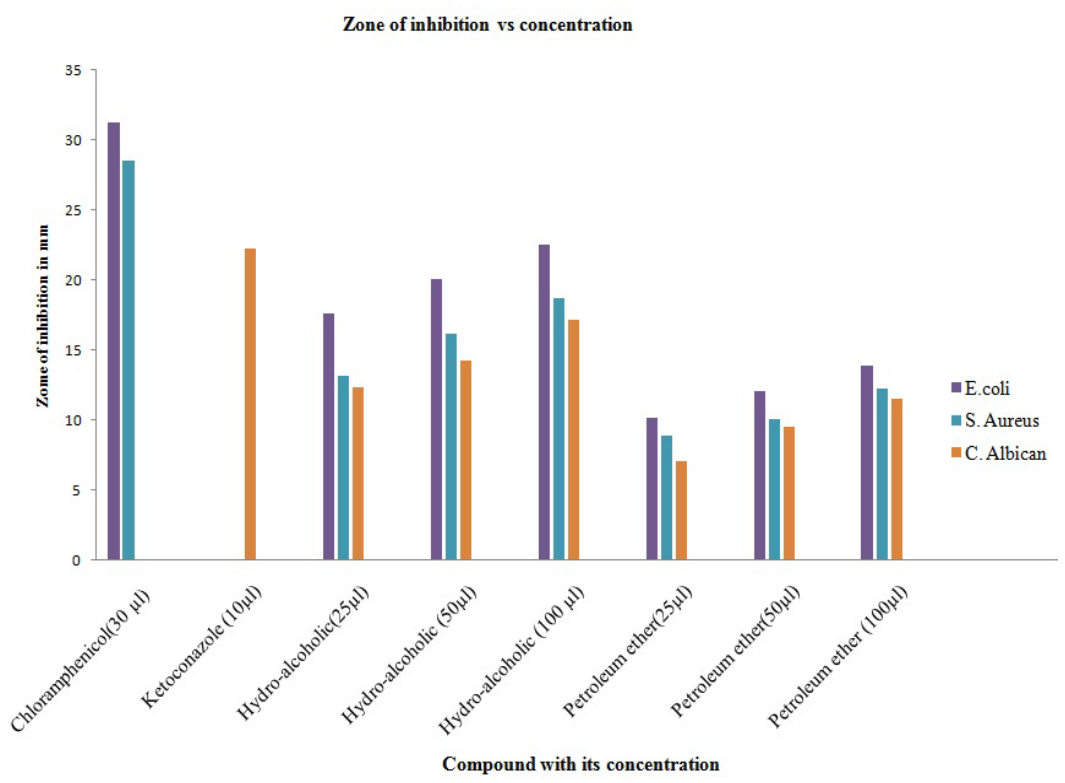

Fig. 1: Zone of inhibition vs concentration

\section{DISCUSSION}

\section{Phytochemical analysis}

The Phytochemical test of Nyctanthes arbortristis root showed the presence of various phytoconstituents. Hydro-alcoholic extract having Carbohydrates, Flavanoids, Tannin, Phenol, Terpenoids, Glycosides, Saponins and petroleum ether extract having Alkaloids, Saponins (table 2).

\section{Anti-bacterial and anti-fungal activity}

The anti-microbial activity of the plant extract of Nyctanthes arbortristis is done by the agar disc diffusion method. Chloramphenicol and Ketoconazole drug taken as the standard for anti-bacterial and anti-fungal activity and it showed the potent activity and the result is given in table 2 .

In case of bacteria, both extract at concentration $25 \mu$ shown the minimum zone of inhibition whereas $100 \mu$ l shown the maximum zone of inhibition against the bacterial strain of Escherichia coli and Staphyllococcus aureus.

In case of fungi, both extract at concentration $25 \mu$ l shown the minimum zone of inhibition whereas $100 \mu$ l shown the maximum zone of inhibition against the fungal strain of Candida albicans.

\section{CONCLUSION}

The hydro-alcoholic and petroleum ether extract of Nyctanthes arbortristis (night flowering jasmine) part root confirms it having antimicrobial property. The antimicrobial activity was evaluated by disk diffusion method, in this study the micro-organisms were taken Staphyllococcus aureus (gram+ve bacteria), Escherichia coli (gramve bacteria), Candida albicans (fungi).

\section{ACKNOWLEDGEMENT}

The authors thankful to Mr. Sumit Das, Assistant Professor Department of Pharmaceutical Chemistry, Girijananda Chowdhury Institute of Pharmaceutical Science, Guwahati, India for his guidance given during this work and Principal and thanks to Department of Microbiology, Girijananda Chowdhury Institute of Pharmaceutical Science, Guwahati for conveying this exploration work. And special thanks to Bikash gupta for his support and being with me.

\section{AUTHORS CONTRIBUTIONS}

All the author have contributed equally

\section{CONFLICT OF INTERESTS}

\section{Declare none}

\section{REFERENCES}

1. Vats M, Sharma N, Sardana S. Antimicrobial activity of stem bark extracts of Nyctanthes arbortristis Linn.(Oleaceae) Inter Nyctanthes arbortristisional. J Pharmacogn Phytochem Res 2009;1:12-4.

2. Meshram MM, Rangari SB, Kshirsagar SB, Gajbiye S, Trivedi MR, Sahane RS. Nyctanthes arbortristis-a herbal panacea. Inter Nyctanthes arbortristisional. J Pharm Sci Res 2012;3:2432-40. 
3. Kiew R, Baas P. Nyctanthes is a member of Oleaceae. Proc Indian Acad Sci 1984;3:349-58.

4. Kurian S, Josekumar VS. Phytochemical screening, antimicrobial activity and brine shrimp lethality bioassay of different extracts of Alysicarpus vaginalis var. nummularifolius (DC.) MIQ. (family: fabaceae). Int J Pharm Sci 2017;9:1-6.

5. Gowdhami T, Rajalakshmi AK, Sugumar N, Valliappan R Evaluation of antimicrobial activity of different solvent extracts of aromatic plant: Jasminum sambac linn. Int J Res Pharm Sci 2015;5:18-23.

6. Kokate CK. Pharmacognosy. Nirali publication; 2007. p. 97-132

7. Woisky R, Salatino. Screening of Indian plants for biological activity. Part II. A. J Agric Res 1998;37:99-105.

8. Bauer AW, Kirby WMM, Scherris JC, Turck M. Antibiotic susceptibility testing by a standardized single disk method. Am J Clin Pathol 1966;45:493-6. 